\title{
Prediksi Akumulasi Sedimen Berdasarkan Survei Batimetri dan Hidrodinamika di Pesisir Teluk Mandeh, Kabupaten Pesisir Selatan, Sumatera Barat
}

\author{
Guntur A. Rahmawan ${ }^{1 *}$, Ulung J. Wisha', Wisnu A. Gemilang ${ }^{1}$, Ilham ${ }^{1}$ dan \\ Semeidi Husrin ${ }^{2}$
}

'Loka Riset Sumber Daya dan Kerentanan Pesisir, Kementerian Kelautan dan Perikanan 2Pusat Riset Kelautan, Kementerian Kelautan dan Perikanan JI. Raya Padang Painan KM. 16 Bungus, Padang, Sumatera Barat 25245

Email: guntura06@gmail.com

\section{Abstract \\ Accumulated Sediment Prediction Based on Bathymetry Survey and Hydrodynamics Approach in Mandeh Coastal Bay, Pesisir Selatan Regency, West Sumatera}

Mandeh Bay is a semi-enclosed water area that there are two main estuaries, Mandeh and Nyalo River estuary. The sedimentation issue has been gotten worse due to the massive development in the coastal area. This study aims to determine the sediment accumulation within Mandeh bay and its distribution patterns. The measurement of sedimentation rate applied in the Mandeh and Nyalo Estuaries. Oceanography parameters (tides and currents) recorded for 30 days measurement. The thickness of sediment accumulation was predicted by applying a single beam echosounder dual-frequency. The calculation of sediment volume was done using a frustum formula grid of $10 \times 10$ meters. The flow model approach was also simulated to depict the distribution pattern of sediment. The thickness of sediment accumulation categorized into five spatial categories that are $0-0.3 \mathrm{~m}, 0.4-0.6 \mathrm{~m}, 0.7-0.9,1-1.2 \mathrm{~m}$, and $1.3-1.5 \mathrm{~m}$. The sedimentation rate in

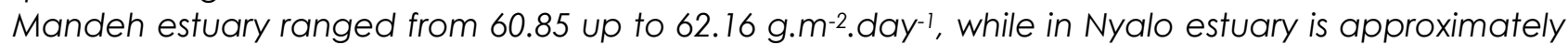
$48.86 \mathrm{~g} \mathrm{~m}^{-2} . \mathrm{day}^{-1}$. The tidal current speed that is weak ranged from $0-0.05 \mathrm{~m} / \mathrm{s}$ induces the sediment accumulation which mainly occurs during the neap tidal conditions. The thickness of sedimentation, which is approximately one meter, is identified around Mandeh River estuary and several areas near Carocok Tarusan Port where the sediment intake takes place. Because of the weak current features, the sedimentation event increased in this region.

Keywords: Sedimentation; bathymetry; hydrodynamics; Mandeh Bay

\begin{abstract}
Abstrak
Teluk mandeh merupakan kawasan teluk semi tertutup yang mempunyai 2 muara sungai besar yaitu sungai Mandeh dan sungai Nyalo. Masalah sedimentasi menjadi semakin parah karena pengembangan wilayah pesisir yang masif. Tujuan dari penelitian ini adalah untuk mengetahui ketebalan akumulasi sedimen di dalam Teluk Mandeh dan pola distribusinya. Pengukuran laju sedimentasi dilakukan pada dua fokus area yakni muara Sungai Mandeh dan Sungai Nyalo. Pengukuran parameter oseanografi (arus dan pasang surut) dilakukan selama 30 hari pengukuran. Ketebalan akumulasi sedimen diukur menggunakan alat Single Beam Echosounder Dual Frekuensi. Perhitungan volume sedimen dihitung dengan rumus frustum grid 10x10 meter. Simulasi flow model juga dilakukan untuk mengetahui pola distribusi sedimen. Sebaran ketebalan sedimen yang dibagi dalam 5 kategori spasial yakni 0-0,3m, 0,4-0,6m, 0,7-0,9,1-1,2m, dan 1,3-1,5m. Laju sedimentasi di muara Sungai Mandeh berkisar antara 60,85 sampai 62,16 g.m-2.hari-1 dan di muara Sungai Nyalo rata-rata 48,86 g.m-2.hari-1. Kecepatan arus pasang surut yang cukup lemah berkisar antara 0-0,05 $\mathrm{m} / \mathrm{s}$ menyebabkan potensi akumulasi sedimen akan berlangsung terutama saat kondisi perbani. Sedimen dengan ketebalan lebih dari 1 meter teridentifikasi di sekitar Sungai Mandeh dan
\end{abstract}


beberapa Kawasan Pelabuhan Carocok Tarusan dimana asupan sedimen mendominasi. Karena karakteristik arus yang lemah, sedimentasi meningkat diwilayah ini.

Kata kunci : Sedimentasi; batimetri; hidrodinamika; Teluk Mandeh

\section{PENDAHULUAN}

Pengangkutan sedimen melalui sungai ke lautan merupakan jalur yang penting dalam siklus geokimia global dan komponen kunci dari sistem denudasi tanah (Walling et al., 2003). Pengangkutan sedimen halus ke sungai merupakan fenomena alam, dan dasar tingkatan sedimen dalam sistem fluvial sangat penting untuk proses penyaluran, heterogenitas habitat, dan fungsi ekologis (Foster et al., 2011). Rekam jejak pengendapan sedimen dalam jangka waktu panjang menunjukan bahwa fluks sedimen sungai dipengaruhi oleh banyak faktor, termasuk perubahan iklim, tataguna lahan yang secara tidak langsung meningkatkan pengangkutan sedimen ke dalam aliran (Houben et al., 2006). Pengangkutan sedimen ke aluran sungai di banyak daerah-daerah di dunia meningkat karena banyaknya perubahan area tangkapan air karena aktivitas manusia seperti pertanian (Collins dan Walling, 2007), pembukaan lahan hutan, pembangunan, pertambangan dan cekungan saluran air area perkotaan (Duerdoth et al., 2015).

Perluasan lahan pertanian maupun pembukaan lahan hutan secara intensif memiliki potensi untuk meningkatkan tekanan sedimen pada aliran air (Wagenhoff et al., 2011). Hubungan antara bentuk saluran sungai dan proses merupakan salah satu faktor pengaturan yang peka dari morfologi sungai sebagai kontrol dan akibat dari proses fluvial (Brasington et al., 2003). Kawasan Mandeh dimanfaatkan oleh pemerintah kabupaten untuk dikembangkan menjadi daerah wisata (Mukhtar et al., 2016).

Kegiatan pembalakan hutan mangrove seluas 1,2 Ha di Kawasan Wisata Bahari Terpadu Mandeh (KWBT), Kab.Pesisir Selatan dirusak (Mukhtar et al., 2016). Teluk Mandeh merupakan suatu daerah yang memiliki lingkungan pengendapan transisional yakni interaksi antara sungai dan laut yang membentuk lingkungan delta. Hal ini akan mempengaruhi distribusi tiap ukuran butir sedimen yang mencerminkan faktor fluiditas dan energi pengendapan (Hidayat dan Rozamuri, 2016). Salah satu penyebab kerusakan terumbu karang yang terjadi di perairan teluk Mandeh diduga karena faktor sedimentasi. Pentingnya manajemen pantai yang berkelanjutan untuk pengembangan wilayah pesisir telah diakui oleh pemerintah kota dan pemerintah lokal (Phillips dan Jones, 2006).

Manajemen pantai harus diarahkan untuk mencapai penggunaan fisik yang optimal dan pengembangan sumber daya pantai dengan memperhatikan elemen fisik alami dari lingkungan pantai serta memenuhi dasar kebutuhan sosial dalam lingkungan pantai (Zacarias et al., 2011). Memahami dinamika sedimen dalam lingkungan yang kompleks merupakan manajemen yang benar dan penting dalam proses mitigasi atau perlindungan terhadap ekosistem dari dampak aktifitas manusia (Ferrarin et al., 2016). Pada kawasan perairan Teluk Mandeh terdapat beberapa muara sungai utama dan besar yang menjadi salah satu faktor pemicu peningkatan sedimentasi. Oleh karena itu, penyelidikan transportasi sedimen secara eksperimental sangat butuh dilakukan (Villatoro et al., 2010).

Beberapa penelitian terdahulu terkait dengan sedimentasi belum banyak dilakukan. Hidayat dan Rozamuri (2016) menganalisis granulometri di Sungai Mandeh dan Sungai Nyalo yang menunjukkan ukuran butir pasir sedang hingga kasar. Selain itu, Wisha et al. (2019) mensimulasikan arus pasang surut dan pengaruhnya terhadap distribusi sedimen di dalam Teluk Mandeh. Sehingga, sebuah studi terkait dengan akumulasi sedimen di teluk mandeh menjadi penting untuk dilakukan. Dalam penelitian ini akan digunakan pendekatan model hidrodinamika dan survei batimetri untuk mengetahui akumulasi sedimen di dalam 
Teluk Mandeh. Penelitian ini bertujuan unutuk mengetahui ketebalan akumulasi sedimen dan mekanisme distribusi sedimen di dalam Teluk Mandeh.

\section{MATERI DAN METODE}

Pengukuran sedimentasi dilakukan dengan menggunakan Echosounder Echotrack CVM Teledyne Odom Hydrographic dual frekuensi. Pengambilan data lapangan dilakukan melalui survei batimetri pada bulan mei tahun 2015 di sekitar perairan laut Teluk Mandeh. Sebelum melakukan kegiatan pemeruman, tranducer yang terpasang harus melakukan pengecekan barcheck (kalibrasi kedalaman) menggunakan piringan logam yang ditempatkan tepat dibawah tranducer (Trincardi et al., 2014).

Piringan logam tersebut diatur pada kedalaman $1 \mathrm{~m}$ dan 5 meterpada perairan yang tenang untuk disesuaikan pada pembacaan pada channel 1 maupun channel 2 pada transducer. Channel 1 merupakan saluran dengan frekuensi tinggi $200 \mathrm{kHz}$ yang mampu membaca nilai kedalaman lapisan atas dasar laut, sedangakan channel 2 berada pada gelombang $33 \mathrm{kHz}$ yang mampu menembus lapisan lumpur. Kedua saluran gelombang tersebut bekerja bersamaan tanpa mengganggu satu sama lain. Untuk mengetahui posisi kedalaman perairan maka dihubungkan alat GPS yang terpasang pada kapal dan merekam posisi di laut sehingga tidak diperlukan kontrol horizontal dari titik tetap yang ada di darat. Untuk mendapatkan nilai kedalaman yang baik desain lajur perum dibuat dengan interval perekaman 200 meter tiap jalurnya dengan pola yang sejajar paralel yaitu arah sonding tegak lurus dan cenderung sejajar dengan garis pantai (Nugraha et al., 2013).

Nilai kedalaman yang didapat kemudian dikoreksi terhadap pasang surut terhadap waktu pengukuran data pasang surut yang digunakan adalah data pasang surut bulan mei 2015 yang di download dari www.ioc-sealevelmonit oring.org/. Kedalaman yang didapat setelah perhitungan pasang surut kemudian diolah dan di plot untuk mendapatkan sebaran posisi dan kedalaman yang terekam oleh tranducer. Ketebalan sedimen didapatkan dari selisih volume antara channel 1 sebagai lapisan atas terhadap channel 2 sebagai lapisan bawah. Perhitungan volume menggunakan metode grid volume dengan ukuran grid $10 \mathrm{~m} \times 10 \mathrm{~m}$ pada areal pemeruman (Gambar 2).

Perhitungan grid menggunakan rumus frustum seperti pada persamaan Rauf dan Winarno (2017). Dari hasil perhitungan volume tersebut dapat diketahui estimasi dan sebaran ketebalan sedimen yang ada di perairan Teluk Mandeh tahun 2015.

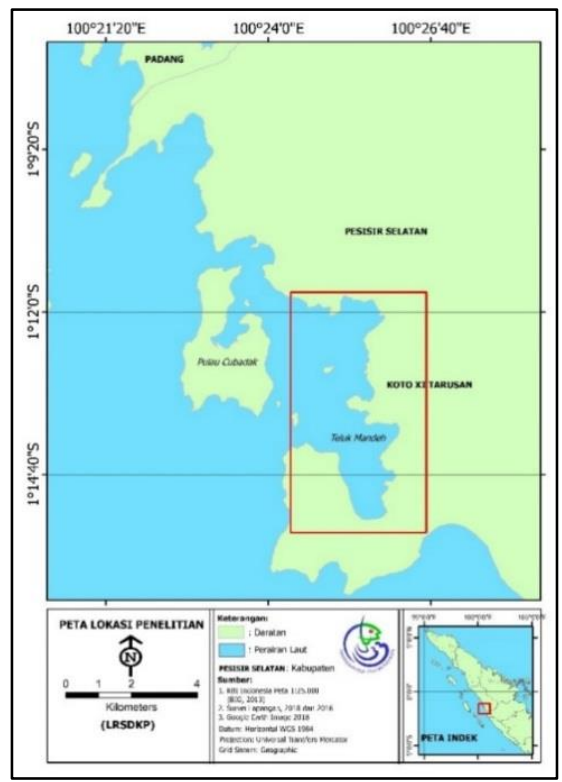

Gambar 1. Peta Lokasi Penelitian(Garis Merah wilayah laut)

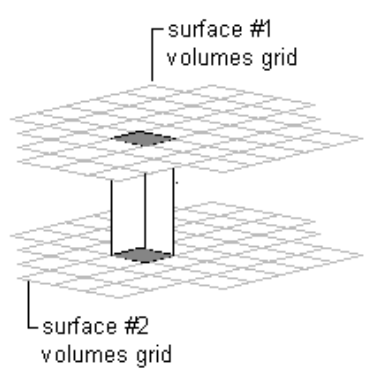

Gambar 2. Simulasi perhitungan grid volume

Pengukuran data oseanografi dilakukan pada bulan Juni 2015 dengan menggunakan alat ADCP (Acoustic Doppler Current Profiler) yang dapat merekam data pasang surut dan arus laut. Data pasang 
surut yang diapatkan di lapangan akan diolah dalam bentuk analisis julat pasang surut dan juga digunakan sebagai validasi model hidrodinamika. Sedangkan, data arus akan diolah dalam bentuk mawar arus. ADCP dipasang selama 30 hari selama bulan Juni-Juli 2018 pada kedalaman 20 meter.

Simulasi model hidrodinamika merupakan sebuah pendeketan numerik yang dapat menggambarkan kondisi oseanografi di perairan yang akan ditampilkan pada empat kondisi ekstrim pasang surut. Simulasi dilakukan sekali selama 15 hari yang mewakili kondisi purnama dan perbani. Data peralaman pasang surut juga digunakan sebagai inputan model hidrodinamika. Flow model dengan flixle mesh digunakan dalam simulasi ini yang didasarkan pada persamaan Navier-Stokes yang terdiri dari permsamaan kontinuitas dan momentum.

\section{HASIL DAN PEMBAHASAN}

Pada hasil pengamatan pada Gambar 3A menunjukkan kedalaman pada Teluk Mandeh berkisar dari 25 - $50 \mathrm{~m}$ dan pada Pulau Cubadak menunjukkan adanya palung diwilayah tersebut dengan kedalam 225-255 $m$, yang diakibatkan oleh aktifitas pergerakan lempeng yang saling menjauh atau yang sering disebut divergen (Hendrizan et al., 2016).

Berdasarkan data kedalaman laut pada Gambar 3B dan dihubungkan dengan morfologi pantai terdapat adanya perbedaan kemiringan morfologi dasar laut yang cukup besar dari pantai (zona pasang surut) ke arah laut. Menurut Rachmat dan Purwanto (2016) Perbedaan morfologi ini akan berpengaruh langsung terhadap tinggi gelombang yang terjadi di sekitar pantai. Dengan kemiringan morfologi dasar laut yang cukup besar di Perairan Teluk Mandeh, daerah gelombang pecah (breaker zone) relatif dekat dengan pantai, serta tidak terbentuknya longshore bar yang berfungsi sebagai peredam alami energi gelombang yang menuju pantai. Oleh karena itu, saat gelombang datang dari laut lepas tidak mengalami peredaman energi oleh dasar laut, sehingga gelombang tidak pecah lebih dulu di laut tapi pecah di daerah pantai. Akibatnya, energi gelombang akan terlepas secara frontal dengan kekuatan besar melalui hempasan (run up) gelombang ke arah pantai dan daratan (Neves et al., 2012). Pada saat kondisi laut pasang, run up gelombang ini akan masuk lebih dalam ke arah teluk dalam bentuk arus sepanjang pantai dan menggerus material yang mudah lepas. Perairan Teluk Mandeh adalah perairan semi tertutup, arus cenderung lebih lemah sehingga mengakibatkan proses pengendapan yang berlangsung secara terus menerus (Wisha et al., 2019).

Gambar 4 memperlihatkan profil kedalaman dari Perairan Laut Mandeh. Kemiringan topografi di Perairan Mandeh Berkisar antara 0,02-0,72 termasuk kategori perairan laut yang landai dan terletak pada kedalaman antara 0-25 meter sejauh 1,5 km dari bibir pantai Perairan Laut Mandeh ke arah Perairan Laut Pulau Cubadak di sisi bagian Timur. Sedangkan dari bibir Perairan Laut Pulau Cubadak ke Arah Pulau Merak dan Perairan Lepas pantai mempunyai kedalaman rata-rata 0- 90 meter. Ada beberapa titik terdapatnya palung laut dengan kedalaman yang bervariasi dengan kedalaman 100-150 m, dan 50-250 m. Morfologi dasar perairan Teluk Mandeh yang cenderung datar berperan dalam pembentukan parameter fisis seperti gelombang dan arus (Wisha et al., 2019) dimana masalah pendangkalan dapat menyebabkan melemahnya dinamika massa air di dalam teluk sehingga akumulasi sedimen cenederung meningkat dan akhirnya dapat merubah bentukan dasar perairan (Wisha dan Heriati, 2016a). Bila kondisi ini terjadi terus-menerus, dapat menyebabkan beberapa dampak terhadap biota maupaun aspek fisis perairan Teluk Mandeh (Mukhtar et al., 2016).

\section{Hidrodinamika Perairan Teluk Mandeh}

Tipe pasang surut di perairan Mandeh adalah pasang surut campuran condong harian ganda, hal ini sesuai dengan penelitian sebelumnya oleh Wisha et al. (2019), yang menyatakan bahwa perubahan elevasi pasang surut terjadi setiap 6 jam 12 menit mempengaruhi pembentukan arus 


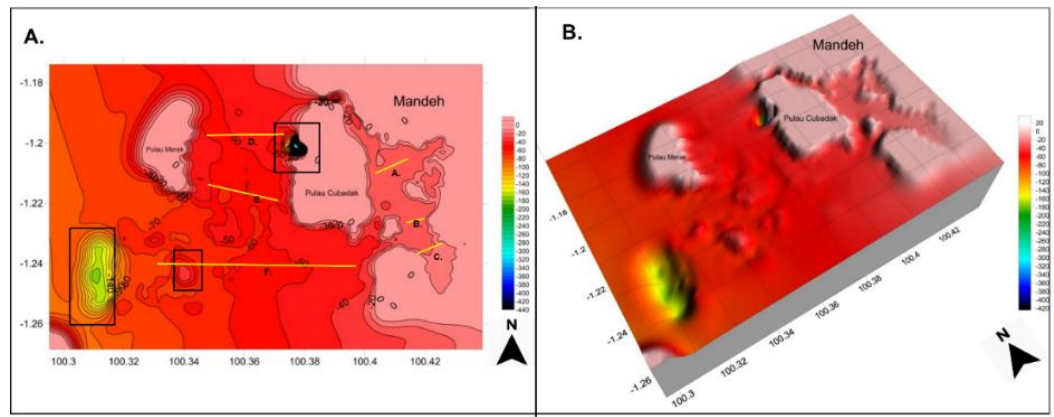

Gambar 3. Profil batimetri Teluk Mandeh. A. Penampang 2-Dimensi. B. Penampang 3-Dimensi. Palung laut disekitar Teluk Mandeh (kotak hitam) dan cuplikan penampang melintang batimetri (garis kuning)

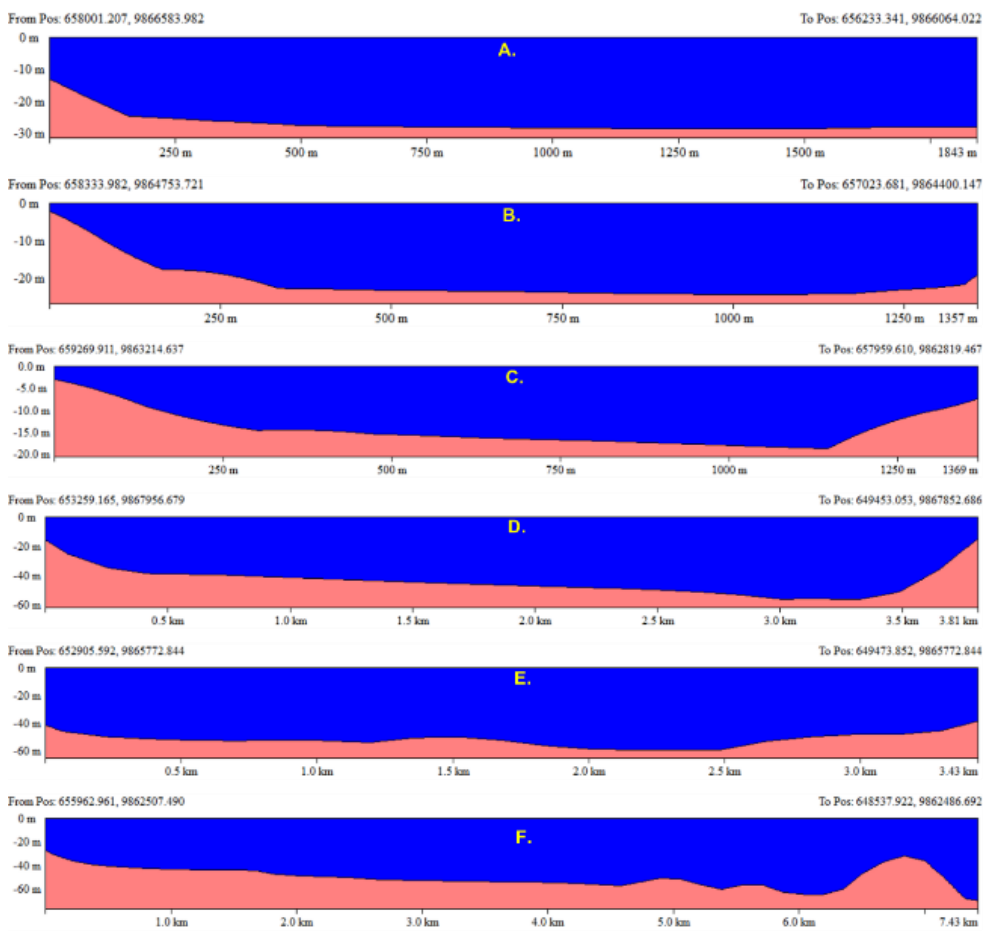

Gambar 4. Penampang melintang profil batimetri di kawasan Mandeh

pasang surut di delam teluk. Berdasarkan analisis julat pasang surut (Gambar 5 dan 6), untuk data pasang naik, saat kondisi purnama perbedaan elevasinya berkisar antara 100-150 cm dan waktu yang dibutuhkan dalam setiap tunggang pasang berkisar antara 3-11 jam. Pada kondisi perbani, elevasi yang terbentuk memiliki selisih sekitar $20 \mathrm{~cm}$ dalam periode 6-10 jam. Jika dianalisis lebih lanjut, fluktuasi tunggang pasang akan selaras dengan perubahan elevasi pasang surut, namun periode dalam mencapai setiap tunggang pasang sangat bervariasi dimana saat purnama periode yang dibutuhkan memiliki rentang waktu yang lebih panjang dan tidak menentu dan sebaliknya, saat kondisi perbani, periode yang dibutuhkan cenderung seragam yakni 6 jam (Wisha dan Heriati, 2016b).

Gambar 5 merupakan hasil analisis julat surut, dimana rentang leveasi yang terbentu lebih rendah $(30-145 \mathrm{~cm})$ jika dibandingkan dengan julat pasang. Pola yang terbentuk menyerupai kondisi pasang surut di perairan Mandeh, namun periode julat yang terbentuk berdasarkan data pengukuran berkisar antara 2-11 jam dengan periode rata-rata 6,5 jam. Perubahan elevasi pasang surut (julat) merupakan faktor utama dalam mekanisme transpor sedimen di wilayah semi-tertutup dimana semakin besar elevasi dan periode 
yang terbentuk, maka kejadian turbulensi dan pengendapan akan semakin intens (Wisha dan Heriati, 2016b). Hal ini akan meningkatkan laju sedimentasi di Teluk Mandeh. Arus pasang surut dan arus sepanjang pantai juga memiliki peran besar dalam peningkatan distribusi sedimen melayang di area pesisir dan pada kondisi tertentu akan terendapkan di dalam teluk (Hidayat dan Rozamuri, 2016).

Dari data current rose (Gambar 7) menunjukkan dominasi kecepatan dan arah arus pada kedalaman tertentu. Pada kedalaman 8,5 m kecepatan arus -10 - 20 $\mathrm{m} / \mathrm{s}$ yang dominan mengarah ke timur dan timur laut dimana kondisi tersebut selaras dengan kedalaman $7,5 \mathrm{~m}, 6,5 \mathrm{~m}$, dan 5,5 m.Berbeda dengan kedalaman yang lain, pada layer $4,5 \mathrm{~m}$ dimana kecepatan arus mencapai $<20 \mathrm{~m} / \mathrm{s}$ dan arahnya pun ada yang di barat daya dan timur. Pada kedalam 3,5 m, 2,5 m, 1,5m menunjukkan perubahan dari kecepatan arus yang signifikan karena pada kedalaman tersebut kecepatan arus mencapai $>20 \mathrm{~m} / \mathrm{s}$ dan arah arus dominannya bergerak kearah Barat Daya. Pola diagram mawar arus juga memperlihatkan mekanisme spiral Ekman yang bergerak berkebalikan dengan jarum jam di belahan bumi selatan (Wisha et al., 2019), di permukaan kecepatan arus lebih tinggi yang disebabkan oleh induksi angin permukaan. Semakin menuju ke dasar kecepatan arus akan berkurang secara bertahap yang diperngaruhi oleh beberapa faktor alam seperti densitas, tekanan, gesekan dasar (Wisha et al., 2015).

Validasi pemodelan hidrodinamika dilakukan dengan menghitung error dari data model dan data lapangan dimana fasa pasang surut surut yang terbentuk hampir sama (Gambar 8), namun terdapat sedikit perbedaan dari elevasi pasang surut yang dibandingkan yakni berkisar antara 0-0,2 meter. Nilai RMSE (Root Mean Square Error) dari perbandingan data model dan data pasang surut mencapai $11.04 \%$, sehingga dapat disimpulkan bahwa model yang dibangun dapat wekalili kondisi yang sebenarnya.

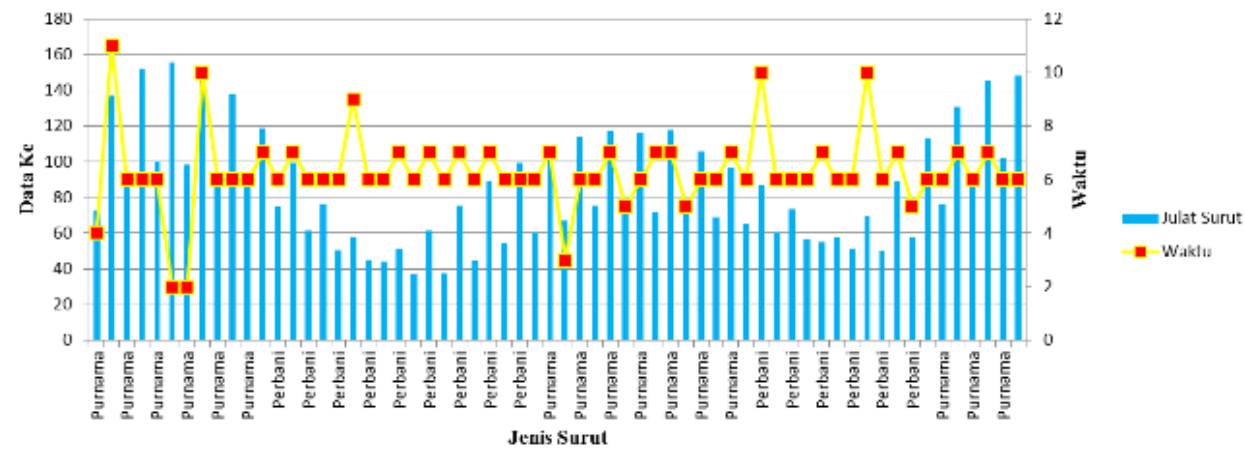

Gambar 5. Julat pasang turun di Teluk Mandeh

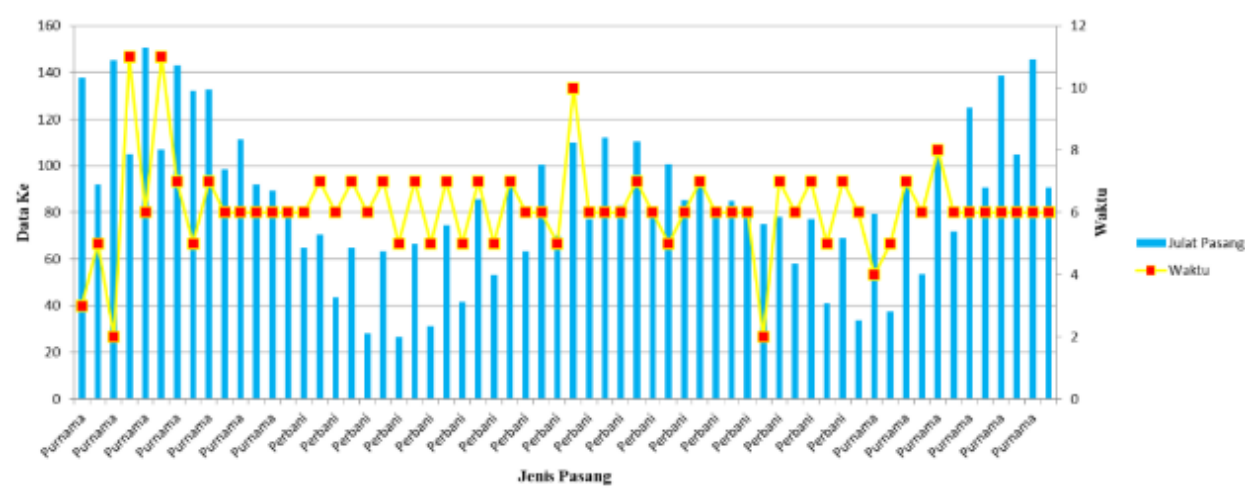

Gambar 6. Julat pasang naik di Teluk Mandeh 
Menurut Chormański et al. (2009) nilai MRSE < $40 \%$ menandakan bahwa model dihasilkan dari simulasi hidrodinamika dapat dijadikan representatif kondisi di alam berdasarkan syarat batas model yang telah dibuat.

Pada kondisi surut perbani, kecepatan dari arusnya sangat lemah karena pada saat perbani gaya dari bumi, bulan, matahari melemah dikarenakan posisi dari bulan, bumi, dan matahari berada dalam garis tegak lurus (Wisha et al., 2015). (Gambar 9A) juga menunjukan pada pantai arus sangat lemah dan mulai meningkat di sekitar Pulau Sutan, Sironjong Ketek, dan Sironjong Gadang, sementara di Pulau Cubadak arus masih lemah. Kecepatan arus pada kondisi Surut Perbani berkisar antara 0,001-0,024 m/s yang berada di sekitar Pulau Sironjong Ketek dan Pulau Sironjong Gadang.
Pada kondisi surut purnama (Gambar 9B), arus dominan bergerak ke arah laut. Arus kuat ditemukan dibagian muara sungai hingga Pulau Sutan. Sedangkan pada Pulau Cubadak arus cenderung melemah. Pada Pulau Sironjong Ketek dan Gadang, kecepatan arus juga cukup tinggi. Kecepatan arus berkisar $0.004-0.055 \mathrm{~m} / \mathrm{s}$. Menurut Wisha et al. (2016) Pada saat pasang tertinggi kecepatan arus menjadi maksimal dan transpor sedimen yang terjadi juga semakin tinggi.

Pada kondisi pasang perbani (Gambar 9C), arus masih lebih dominan ke dalam teluk, dan kecepatan dari arus cenderung lemah, terutama pada daerah garis pantai dengan kecepatan berkisar antara 0.002$0.023 \mathrm{~m} / \mathrm{s}$. Pada kondisi pasang perbani arus akan lebih dominan kearah dalam teluk

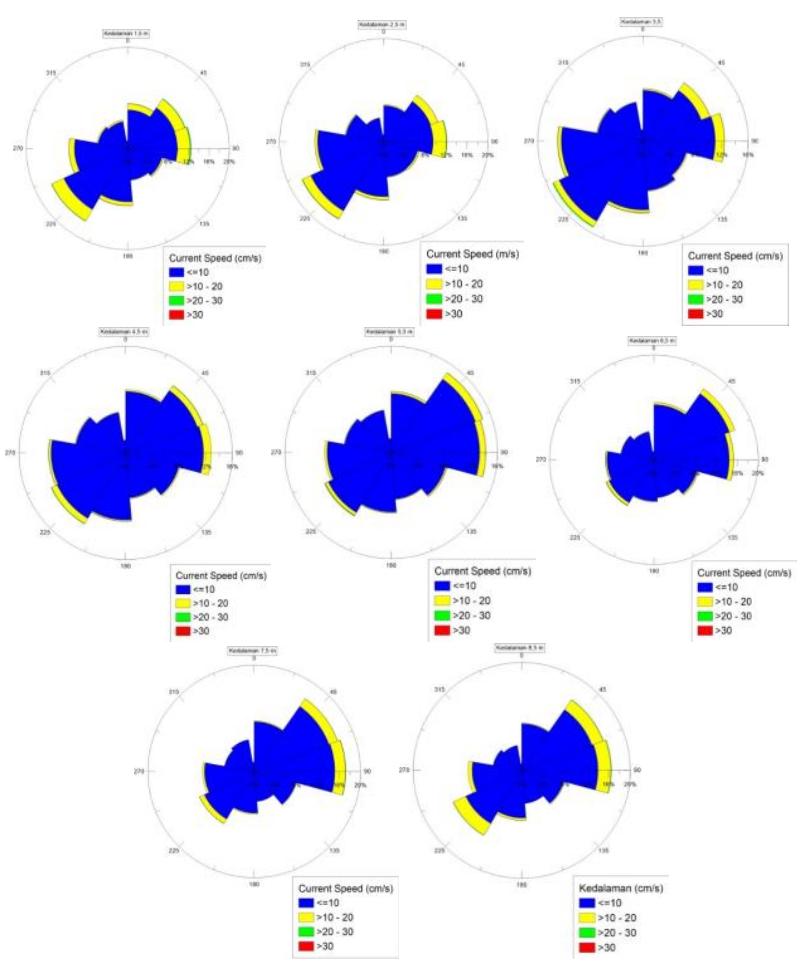

Gambar 7. Mawar arus di Teluk Mandeh

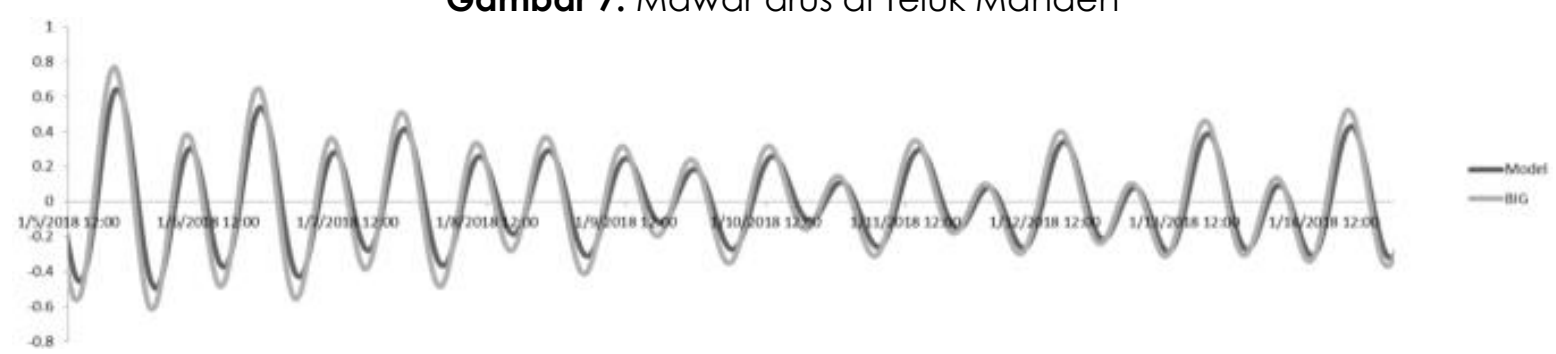

Gambar 8. Validasi hasil model Hidrodinamika 

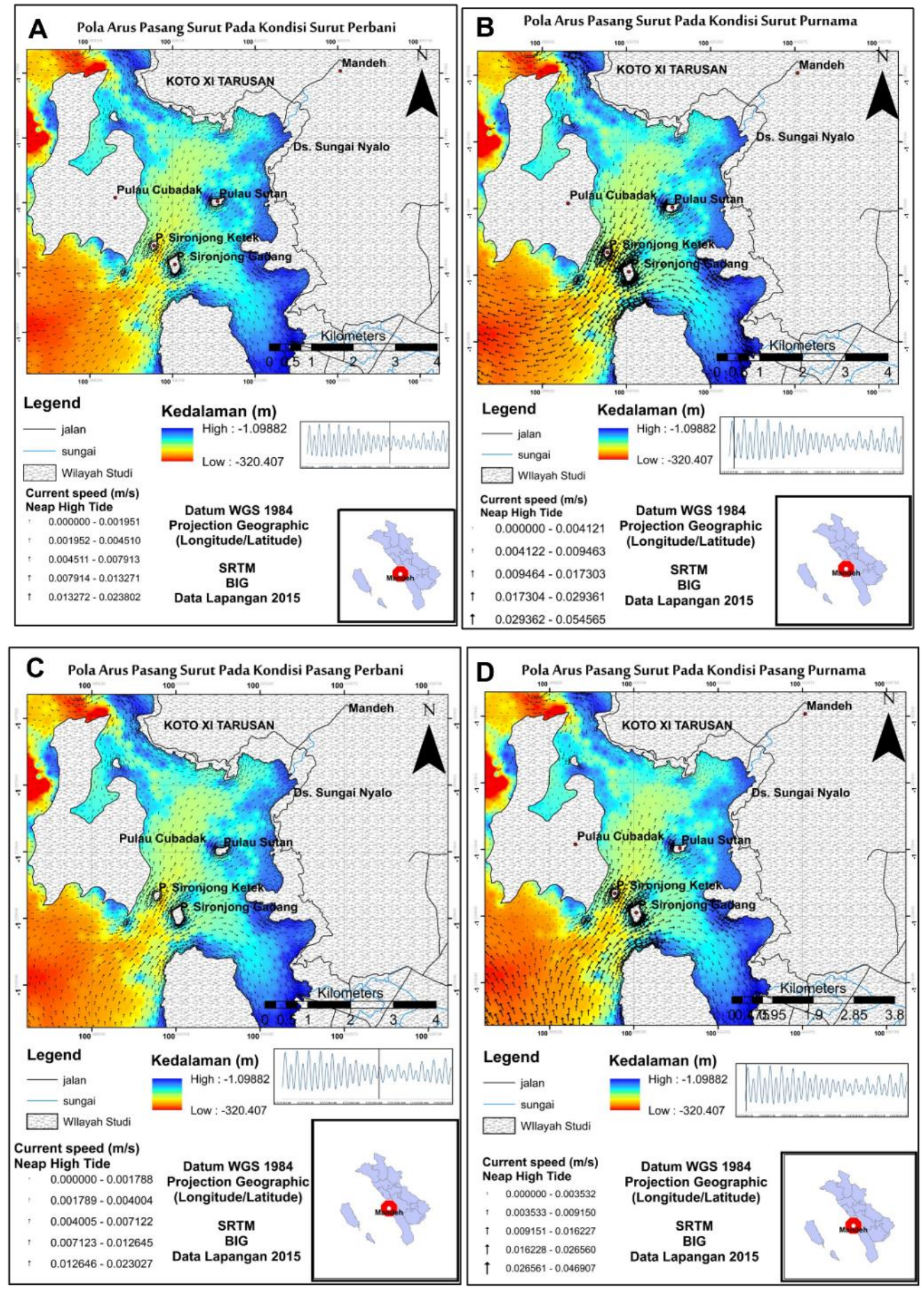

Gambar 9. Pola Arus di Teluk Mandeh pada empat kondisi ekstrim pasang surut

walaupun dengan kecepatan yang lebih rendah bila dibandingkan dengan kondisi purnama. Menurut (Nugroho dan Basit, 2014) ketika adanya arus yang kuat, sedimen yang memiliki fraksi halus akan terbawa mengendap di daerah perairan yang lebih tenang.
Pada kondisi pasang purnama, kecepatan relatif kuat karena pengaruh oleh gaya tarik menarik antara bumi, bulan, dan matahari (Qarnain et al., 2014). Pada Gambar 9D arus kuat saat pasang purnama bergerak dari perairan lepas (Selat Mentawai), dan pada Pulau Cubadak, 
Sironjong Ketek, dan Sironjong Gadang kecepatan arus semakin meningkat, tetapi semakin ke pantai/daratan kecepatan arus menjadi lemah karena banyak bangunan pemecah ombak, bukan hanya dipantai tersebut tapi di pulau - pulau yang berada di sekitar teluk tersebut dimana kecepatan 0,004 berkisar antara $0,047 \mathrm{~m} / \mathrm{s}$.

\section{Dinamika Sedimentasi Dasar Perairan Teluk Mandeh}

Hasil perhitungan volume antara channel 2 terhadap channel 1 didapatkan bahwa volume sedimen yang ada di Teluk Mandeh sebesar 2.362.372 $\mathrm{m}^{3}$. Jumlah tersebut tersebar secara tidak merata pada kawasan perairan laut teluk mandeh sedangkan ketebalan sedimen rata-rata adalah sebesar $0.30 \mathrm{~m}$ dengan luasan penelitian sebesar $78,52 \mathrm{~km}^{2}$. Sebaran ketebalan sedimen tertinggi ada pada sisi sebelah utara dan sebelah selatan perairan teluk mandeh dengan ketebalan antara 0.7 sampai dengan $>1.5$ meter yang ditunjukkan dengan warna kuning hingga ke merah (Gambar 10), selain itu pada sisi sebelah utara terdapat muara sungai Mandeh dan Sungai Nyalo yang merupakan salah satu penyuplai sedimen paling besar yang berasal dari darat (Hidayat and Rozamuri, 2016).

Bentuk topografi pantai pada sisi sebelah utara yang cekung kedalam seperti teluk di dalam teluk sangat mempengaruhi kekuatan arus, dimana arus bawah membawa material sedimen, sehingga pada kawasan tersebut terjadi penumpukan sedimen yang lebih tinggi dibandingkan dengan kawasan yang lainnya, proses sedimentasi disebabkan oleh adanya arus yang ada di bawah perairan dan adanya tektonik aktif (Bohoyo et al., 2019). Gemilang et al. (2017) juga menyatakan bahwa mekanisme transpor sedimen sangat dipengaruhi oleh faktor oseanografi.

Sisi sebelah selatan perairan teluk mandeh (Kawasan Pantai Carocok) juga terdapat sedimentasi yang cukup tinggi dengan kisaran ketebalan 0,7-1,5 meter. Kawasan wisata pantai dengan terdapatnya pelabuhan yang memungkinkan tingginya sedimentasi. Salah satu masalah yang ada adalah tingginya sedimentasi yang disebabkan oleh berubahnya energi dan pergerakan arus laut sehingga transpor sedimen juga akan mengalami perubahan dari kondisi normalnya.

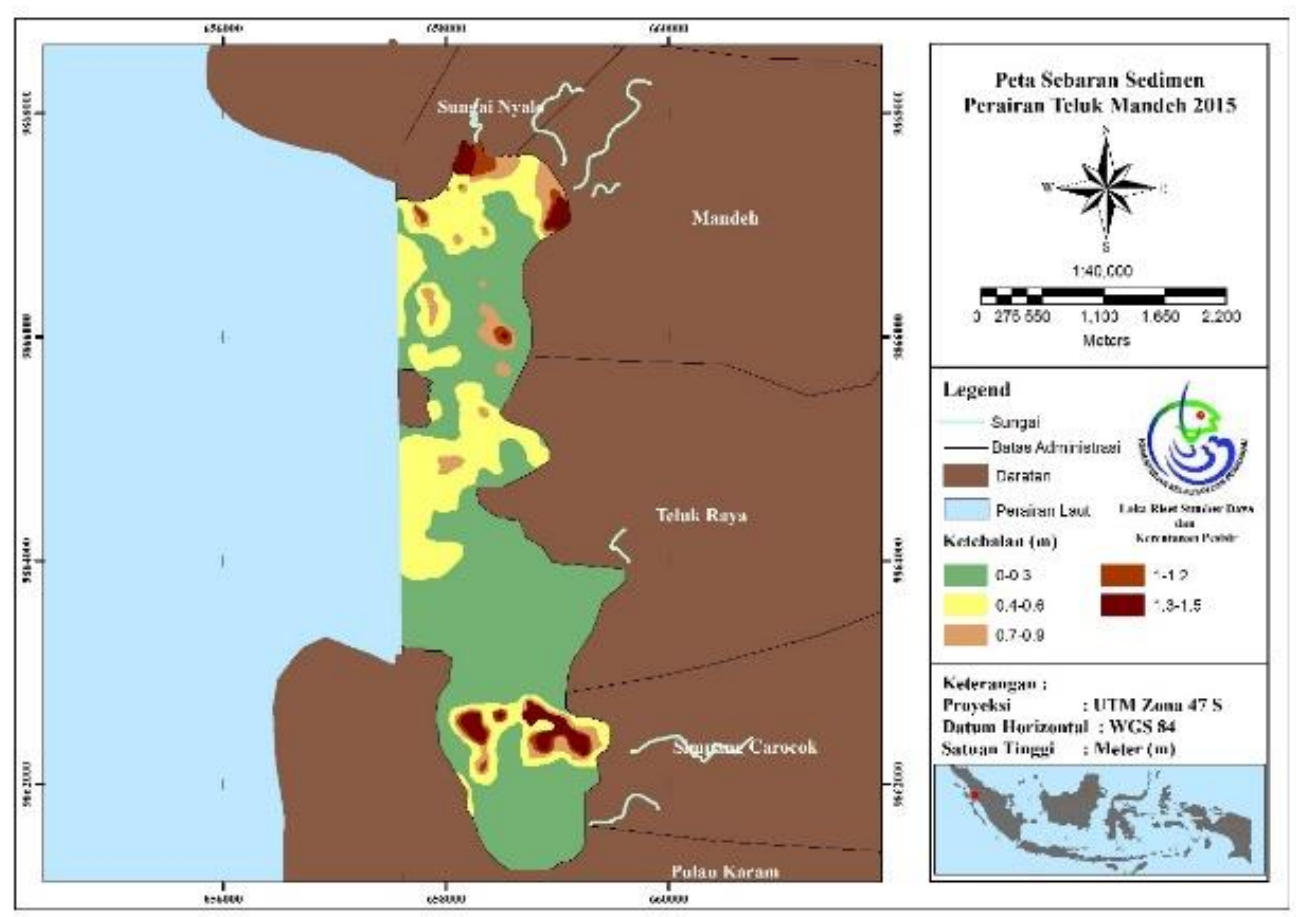

Gambar 10. Peta ketebalan sedimen perairan Teluk Mandeh 
Kisaran nilai laju sedimentasi di muara Sungai Mandeh adalah sebesar 60,85 sampai $62,16 \mathrm{~g} \cdot \mathrm{m}^{-2} \cdot$ hari-1 $^{-1}$. Sementara itu, tingkat laju sedimentasi yang didapatkan dari Sungai Nyalo rata-rata 48,86 g.m-2. hari-1. Dengan memperhitungkan hari hujan yang terjadi pada saat pengambilan sampel sedimen, sedimen yang disumbangkan ke Teluk Mandeh dan sekitarnya lebih banyak disumbang dari Sungai Mandeh, hal tersebut sesuai dengan hasil penelitian oleh Hidayat dan Rozamuri (2016). Proses sedimentasi akan berlangsung perlahan dan terus menerus selama suplai muatan sedimen yang banyak dari daratan masih terus terjadi (Gemilang et al., 2017).

\section{KESIMPULAN}

Ketebalan rata-rata di perairan teluk mandeh adalah sebesar $30 \mathrm{~cm}$ tersebar dibeberapa kawasan perairan teluk. Penumpukan sedimen paling besar ada sekitar kawasan muara sungai mandeh, Sungai nyalo dan beberapa kawasan di Pelabuhan Carocok Tarusan. Laju sedimentasi yang cukup tinggi dan pengaruh dari arus pasang surut yang lemah pada daerah semi tertutup menyebabkan terjadinya akumulasi sedimen dan pendangkalan di dalam Teluk Mandeh.

\section{UCAPAN TERIMAKASIH}

Terimakasih kami sampaikan kepada Loka Riset Sumber Daya dan Kerentanan Pesisir (LRSDKP) atas DIPA anggaran tahun 2015 di Teluk Mandeh dan kepada semua pihak yang telah membantu dalam penyelesaian artikel ini.

\section{DAFTAR PUSTAKA}

Bohoyo, F., Larter, R.D., Galindo-Zaldívar, J., Leat, P.T., Maldonado, A., Tate, A.J., Flexas, M.M., Gowland, E.J.M., Arndt, J.E., Dorschel, B., Kim, Y.D., Hong, J.K., LópezMartínez, J., Maestro, A., Bermúdez, O., Nitsche, F.O., Livermore, R.A. \& Riley, T.R., 2019. Morphological and geological features of Drake Passage, Antarctica, from a new digital bathymetric model. J. Maps. 15(2):49-59. doi : 10.1080/17445647. 2018.1543618
Brasington, J., Langham, J. \& Rumsby, B., 2003. Methodological sensitivity of morphometric estimates of coarse fluvial sediment transport. Geomorphology. 53(3-4):299-316. doi : 10.1016/S0169-555X (02)00320-3

Chormański, J., Mirosław-Świąłek, D. \& Michałowski, R., 2009. A hydrodynamic model coupled with GIS for flood characteristics analysis in the Biebrza riparian wetland. Oceanol. Hydrobiol. Stud. 38:65-73. doi : 10.2478/v10009-0090004-X

Collins, A.L. \& Walling, D.E. 2007. Sources of fine sediment recovered from the channel bed of lowland groundwaterfed catchments in the UK. Geomorphology. 88(1-2):120-138. doi: 10.1016/j.geomor ph.2006.10.018

Duerdoth, C.P., Arnold, A., Murphy, J.F., Naden, P.S., Scarlett, P., Collins, A.L., Sear, D.A. \&, Jones, J.I., 2015. Assessment of a rapid method for quantitative reachscale estimates of deposited fine sediment in rivers. Geomorphology. 230:37-50. doi : 10.1016/j.geomorph. 2014. 11.003

Ferrarin, C., Umgiesser, G., Roland, A., Bajo, M., De Pascalis, F., Ghezzo, M., \& Scroccaro, I., 2016. Sediment dynamics and budget in a microtidal lagoon - A numerical investigation. Mar. Geol. 381:163-174. doi : 10.1016/j.margeo.2016. 09.006

Foster, I.D.L., Collins, A.L., Naden, P.S., Sear, D.A., Jones, J.I. \& Zhang, Y., 2011. The potential for paleolimnology to determine historic sediment delivery to rivers. J. Paleolimnol. 45(2):287-306. doi : 10.1007/ s10933-011-9498-9

Gemilang, W.A., Kusumah, G., Wisha, U.J., \& Arman, A., 2017. Laju Sedimentasi di Perairan Brebes, Jawa Tengah Menggunakan Metode Isotop 210pb. J. Geol. Kelaut. 15:11-22. doi : 10.32693/jgk. 15.1.2017.328

Hendrizan, M., Zuraida, R. \& Cahyarini, S.Y., 2016. Karakteristik Sedimen Palung Laut Sulawesi (Core Sta12) Berdasarkan Hasil Pengamatan Megaskopis Dan Sifat Fisika Dari Pengukuran Multi-Sensor Core Logger (Mscl). J. Ris. Geol. dan Pertamb. 26:69-78. doi : 10.14203/risetgeotam $2016 . v 26.273$ 
Hidayat, R. \& Rozamuri, M.F., 2016. Comparison of Grain-Size Profile and Depositional Process in Mandeh and Nyalo Bar, Mandeh Bay, West Sumatera, Indonesia. J. App. Geo., 1 (1):36-42. doi : $10.22146 / \mathrm{jag} .26958$

Houben, P., Hoffmann, T., Zimmermann, A., \& Dikau, R., 2006. Land use and climatic impacts on the Rhine system (RheinLUCIFS): Quantifying sediment fluxes and human impact with available data. Catena. 66(1-2):42-52. doi : 10.1016/j.catena. 2005.07.009

Mukhtar, P.D., Rudiyanti, S. \& Purwanti, F., 2016. Analysis of Tourism Suitability in Nyalo Coast (Mandeh Region) Pesisir Selatan Regency, West Sumatera. Manag. Aquat. Resour. J. 5:420-426.

Neves, D.R.C.B., Endres, L.A.M., Fortes, C.J.E.M. \& Okamoto, T., 2012. Directional spreading model in a wave channel: Wave propagation and wave breaking. Ocean Eng. doi : 10.1016/j.oceaneng. 2012.07.016

Nugraha, A.R., Saputro, S. \& Purwanto, P., 2013. Pemetaan Batimetri Dan Analisis Pasang Surut Untuk Menentukan Elevasi Lantai Dermaga 136 Di Muara Sungai Mahakam, Sanga - Sanga, Kalimantan Timur. J. Oceanogr. 2:238-244.

Nugroho, S.H. \& Basit, A., 2014. Sediment Distribution Based on Grain Size Analysis in Weda Bay, Noerthern Maluku. J. Ilmu dan Teknol. Kelaut. Trop. 6:229-240. doi : 10.29244/jitkt.v6il.8644

Phillips, M.R. \& Jones, A.L., 2006. Erosion and tourism infrastructure in the coastal zone: Problems, consequences and management. 27(3):517-524. Tour. Manag. doi : j.tourman.2005.10.019

Qarnain, A.G.D., Satriadi, A. \& Setiyono, H., 2014. Analysis of Spring and Neap Tides Influence on the sedimentary rate in Timbulsloko Waters, Demak. J. Oceanogr. 3:540-548.

Rachmat, B. \&Purwanto, C., 2016. Morfologi Dasar Laut Kaitannya Dengan Proses Abrasi Pantai Di Perairan Pulau Marore, Sulawesi Utara. J. Geol. Kelaut. 9:29-43. doi : 10.32693/jgk.9.1.2011.198

Rauf, A., Winarno, E., 2017. Pengaruh Penempatan Garis Sayatan Terhadap Estimasi Sumberdaya Batugamping Di Gunung Pokerso Kabupaten
Gunungkidul-DIY. J. Teknol. Pertamb. 3: 22-29.

Trincardi, F., Campiani, E., Correggiari, A., Foglini, F., Maselli, V., Remia, A., 2014. Bathymetry of the Adriatic Sea: The legacy of the last eustatic cycle and the impact of modern sediment dispersal. J. Maps. 10(1):151-158. doi : 10.1080/174456 47.2013.864 844

Villatoro, M.M., Amos, C.L., Umgiesser, G., Ferrarin, C., Zaggia, L., Thompson, C.E.L. \& Are, D., 2010. Sand transport measurements in Chioggia inlet, Venice lagoon: Theory versus observations. Cont. Shelf Res. 30(8):1000-1018. doi : 10.1016/j.csr.2009.06.008

Wagenhoff, A., Townsend, C.R., Phillips, N., \& Matthaei, C.D., 2011. Subsidy-stress and multiple-stressor effects along gradients of deposited fine sediment and dissolved nutrients in a regional set of streams and rivers. Freshw. Biol. 56(9):1916-1936. doi : $10.1111 / \mathrm{j} .1365-2427.2011 .02619 . x$

Walling, D.E., Owens, P.N., Carter, J., Leeks, G.J.L., Lewis, S., Meharg, A.A. \& Wright, J., 2003. Storage of sediment-associated nutrients and contaminants in river channel and floodplain systems. Appl. Geochemistry. 18(2):195-220. doi : 10.1016/S0883-2927(02)00121-X

Wisha, U.J., Dhiauddin, R., Gemilang, W.A., 2019. Tidal Ellipses Analysis Based on Flow Model Hydrodynamic Data Acquisition in Mandeh Bay, West Sumatera. J. Geosci. Eng. Environ. Technol. 04:93-103. doi : 10.25299/jgeet.2019.4.2.3115

Wisha, U.J., Heriati, A., 2016a. Bathymetry and Hydrodynamics in Pare Bay Waters During Transitional Seasons (SeptemberOctober). Omni Akuatika 12(2):1-10.

Wisha, U.J., Heriati, A., 2016b. Analisis Julat Pasang Surut (Tidal Range) dan pengaruhnya terhadap Sebaran Total Sedimen Tersuspensi (TSS) di Perairan Teluk Pare. J. Kelaut. Indones. J. Mar. Sci. Technol. 9:23-31. doi : 10.21107/jk.v9i1. 1066

Wisha, U.J., Husrin, S., Prasetyo, G.S., 2016. Hydrodynamics of Bontang Seawaters: Its Effects on the Distribution of Water Quality Parameters. Indones. J. Mar. Sci. 21:123-134. doi : 10.14710/ik.ijms.21.3.123134 
Wisha, U.J., Husrin, S. \& Prihantono, J., 2015. Hidrodinamika Perairan Teluk Banten Pada Musim Peralihan (AgustusSeptember). ILMU Kelaut. Indones. J. Mar. Sci. 20:101-112.

doi

10.14710/ik.jjms.20.2.101-112
Zacarias, D.A., Williams, A.T. \& Newton, A., 2011. Recreation carrying capacity estimations to support beach management at Praia de Faro, Portugal. Appl. Geogr. 31:1075-1081. doi : 10.1016/j.apgeog.2011.01.020 